\title{
The Effect of Online Explaining Skills on Teacher Competence
}

\author{
Sixson Roberto Simangunsong ${ }^{1}$, Sabda Dian Nurani Siahaan², Dodi Pramana ${ }^{3}$ \\ ${ }^{1}$ Economic Education, Universitas Negeri Medan, North Sumatera, Medan \\ ${ }^{2}$ Department of Entrepreneurship, Universitas Negeri Medan, North Sumatera, Medan \\ ${ }^{3}$ Department of Office Administration Education, Universitas Negeri Medan, North Sumatera, Medan \\ *Corresponding author. Email: msixson@yahoo.com
}

\begin{abstract}
This study aims to find the effect of teacher skills in explaining online on teacher competence with data collection conducted by researchers to obtain data is to use several methods including online questionnaires, and filled in as many as thirty teacher respondents. Along with the development of technology, education systems which are entirely conventional learning processes are slowly being pursued by data learning processes or what is commonly referred to as online or e-learning. Coupled with the pandemic that has occurred throughout the world including Indonesia at this time, the conventional learning process has been temporarily stopped and has switched to the online learning process which is generally referred to as elearning. E-learning is a distance learning that utilizes electronic media to convey learning, either in the form of the internet, $\mathrm{CD}$ or by using a cellphone. From the results found Kolmogorov normality data from the results it can be concluded that the skills of teachers to explain online on teacher competence can have a positive effect on teacher competence, the results of the analysis of the SPSS state that the validity of the questionnaire is valid, the reliability of the questionnaire is reliable, for the classical assumption test results were also found. Normality test which states that the questionnaire is normally distributed-Smirnov Z is 1,009 which states that the test is normally distributed and Sig. .261. And the ANOVA test obtained states that the overall variable has a good effect with a value of $0.000<$ of the $\mathrm{F}$ value of 1.598 , This can be proven by The calculation together ( $F$ test) obtained a significance of $0.000<0.05$, that is, the hypothesis is accepted, so that it continues to test the hypothesis which has a positive effect, the skills of teachers to explain online have a positive effect on teacher competence.
\end{abstract}

Keywords: Online Explanaining, Teacher Competence

\section{INTRODUCTION}

Increasing human resources is a big and longterm problem because the problem concerns the nation's education. Improving the quality of human resources must go through a good and directed educational process. Education is said to be successful if it can provide the ability, knowledge and skills to graduates to continue higher education or enter the world of work. Through education, students are educated to develop their potential to become qualified, educated and skilled human resources who are able to face very complex challenges and compete in society. Along with the development of technology, education systems which are entirely conventional learning processes are slowly being pursued by data learning processes or what is commonly referred to as online or e-learning. Coupled with the pandemic that has occurred throughout the world including Indonesia at this time, the conventional learning process has been temporarily stopped and has switched to the online learning process which is generally referred to as elearning. E-learning is a distance learning that utilizes electronic media to convey learning, either in the form of the internet, $\mathrm{CD}$ or by using a cellphone. The Indonesian government has actually been developing online learning or online since 2013. The Directorate of Learning and Student Affairs has conducted many trainings and workshops on online learning and enforced regulations regarding quality assurance of online learning. This shows that the government views online learning as an inevitable process in response to technological advances. Entering the beginning of 2020, the world education situation began to fluctuate with the issue of infectious diseases caused by the corona virus. WHO (World Health Organization) calls this disease Coronavirus Disease (Covid-19). However, other countries in Southeast Asia have started to raise 
awareness, including Indonesia. The Covid-19 outbreak is increasingly spreading from time to time, Indonesia is not spared from it. School, like it or not, like it or not, must move to overcome the situation. Schools and campuses must be vacated in an effort to reduce the spread of the virus. On March 16, 2020, in connection with an Extraordinary Event (the spread of the Covid-19 virus), the Indonesian people implemented regulations.for Home Study (BDR). Therefore, the learning process becomes $100 \%$ online learning (online). (Sobron AN, 2019)Online Learning itself can be understood as formal education organized by elementary schools whose students and instructors (teachers) are in separate locations so that it requires an interactive telecommunications system to connect the two and the various resources needed therein. Learning is anything that can carry information and knowledge in the interactions that take place between educators and students. Pedagogical competence relates to the ability to manage learning in order to actualize the various potentials possessed by students. One of the abilities demanded from this competency is the ability to carry out educational learning. In order to carry out educational learning properly, in addition to mastering various abilities, teachers are required to master basic teaching skills, which are one of the important aspects of teacher competence. So the challenge is, how so that in online schools or online lectures, educators are able to convey the basic concepts that students must have, foster the artistic abilities of students in the field of study to conduct analysis and assessment. So that in this paper, the team of writers is interested in conducting research related to the title raised, namely the Effect of Explaining Online Learning Skills on Teacher Competence.

\section{METHOD}

This study uses a quantitative approach. With this type of correlational research, the research design used aims to determine the relationship between two or more variables. The nature of the research is causal correlation or influence research. That is, "it is called causal research because there is a causal relationship between the first and second conditions. The first state is thought to be the cause of the second, the first state affects the second ".In this study, there are two variables involved, the first variable (independent variable), namely the ability to explain the teacher's skills, is estimated to be the cause or effect of the second variable (dependent variable), namely Teacher Competence. The approach that I use in this research is a quantitative approach, meaning that it emphasizes the analysis on numerical data (numbers) processed by statistical methods. Based on the description above, it can be understood that the type of research that the author carries out is quantitative research, and the nature of the research is causal or effect correlation research using a quantitative approach. With a quantitative approach, the writer wants to know how much influence the ability of explaining skills of teachers to teacher competence.

\section{RESULT AND DISCUSSION}

In statistical analysis, statistical tests that can be used to measure the normality of data are using the Kolmogorov-Smirnov (KS) statistical test. The basis for making decisions based on probability or significance.

\section{One-Sample Kolmogorov-Smirnov Test}

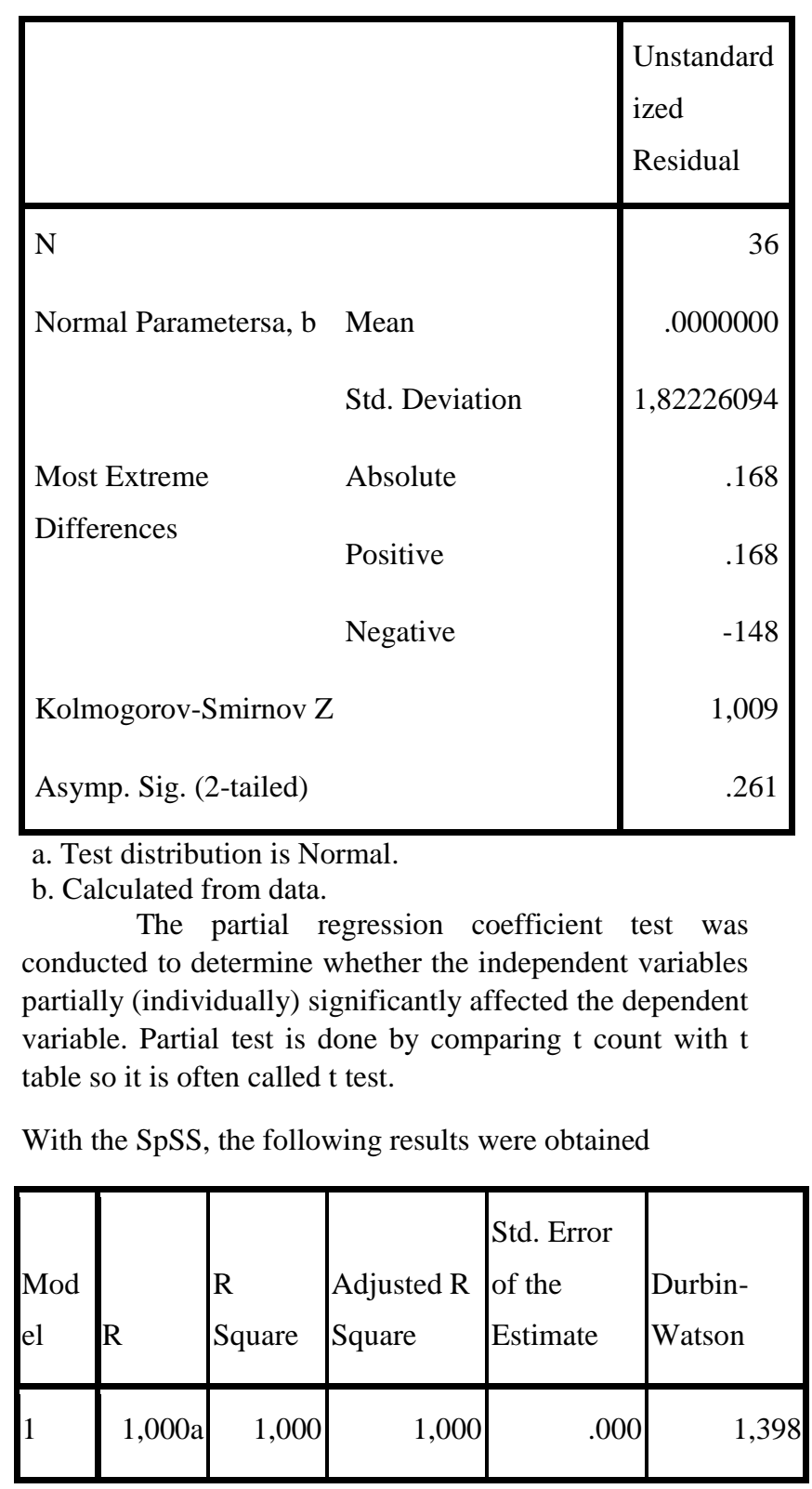




\begin{tabular}{|r|l|r|l|l|l|}
\hline Model & $\begin{array}{l}\text { Sum of } \\
\text { Squares }\end{array}$ & df & $\begin{array}{l}\text { Mean } \\
\text { Square }\end{array}$ & F & Sig. \\
\hline $1 \quad \begin{array}{l}\text { Regressi } \\
\text { on }\end{array}$ & 1803,886 & 15 & 120,259 & 1.598 & $.000 \mathrm{a}$ \\
$\quad \begin{array}{l}\text { Residual } \\
\text { Total }\end{array}$ & 1803,886 & 34 & .000 & & \\
\hline
\end{tabular}

\subsection{Our Contribution}

This paper presents the results of research on the effect of online teaching skills on teacher competence in the present, and the research results are obtained based on the results of a questionnaire instrument distributed to several teachers.

\subsection{Paper Structure}

Other papers are organized as follows. The first part is the background of the problem, and is followed by the second part is the theoretical framework, then the third part is designing a quantitative research method with multiple regression analysis, and finally it is followed by the results of the discussion and conclusions.

\section{CONCLUSION}

Along with the development of technology, education systems which are entirely conventional learning processes are slowly being pursued by data learning processes or what is commonly referred to as online or e-learning. Coupled with the pandemic that has occurred throughout the world including Indonesia at this time, the conventional learning process has been temporarily stopped and has switched to the online learning process which is generally referred to as elearning. E-learning is a distance learning that utilizes electronic media to convey learning, either in the form of the internet, $\mathrm{CD}$ or by using a cellphone.From the results found Kolmogorov normality data from the results it can be concluded that the skills of teachers to explain online on teacher competence can have a positive effect on teacher competence, the results of the analysis of the SPSS state that the validity of the questionnaire is valid, the reliability of the questionnaire is reliable, for the classical assumption test results were also found. Normality test which states that the questionnaire is normally distributedSmirnov $\mathrm{Z}$ is 1,009 which states that the test is normally distributed and Sig. .261. And the ANOVA test obtained states that the overall variable has a good effect with a value of 0.000 <of the $\mathrm{F}$ value of 1.598 , This can be proven by The calculation together ( $\mathrm{F}$ test) obtained a significance of $0.000<0.05$, that is, the hypothesis is accepted, so that it continues to test the hypothesis which has a positive effect, the skills of teachers to explain online have a positive effect on teacher competence.

\section{ACKNOWLEDGMENT}

This work is done by authors who have examined the instruments that have been distributed to respondents who work as teachers

\section{REFERENCES}

[1] Sudjana. 2017. Metoda Statistika. Bandung: Tarsito.

[2] Sugiyono. 2016. Metode Penelitian Kuantitatif, Kualitatif dan R\&D. Bandung: Alfabeta.

[3] Khusniyah, N. L., \& Hakim, L. (2019). EFEKTIFITAS PEMBELAJARAN BERBASIS DARING : 17(1), 19-33. Menyusun, D., \& Pelaksanaan, R. (2019). Jurnal PAJAR ( Pendidikan dan Pengajaran ) Volume 3 Nomor 4 Juli 2019 | ISSN Cetak : 2580 - 8435 | ISSN Online : 2614 - 1337 Jurnal PAJAR ( Pendidikan dan Pengajaran ) Volume 3 Nomor 4 Juli 2019 | ISSN Cetak : 2580 - 8435 | ISSN Online : 2614 - 1337. 3(November), 782-790.

[4] Safitri, D. P., \& Ariani, D. (2018). Jurnal Pembelajaran Inovatif Evaluasi Kompetensi Pedagogik Guru Pasca Pelatihan Guru Pembelajar Moda Daring. 1(159), 33-36.

[5] Sobron, A. N., \& Meidawati, S. (2019). PERSEPSI SISWA DALAM STUDI PENGARUH DARING LEARNING TERHADAP MINAT BELAJAR IPA Universitas Veteran Bangun Nusantara Sukoharjo Email : nugrahaadi7650@gmail.comm. 1(2), 30-38.

[6] Sobron A.N. (2019). Pengaruh Daring Learning terhadap Hasil Belajar IPA Siswa Sekolah Dasar. ISBN : 978-602-99975-3-8, 1-5.

[7] Drs. Zainal Asril. 2010. Micro Teaching. Jakarta: PT Raja Grapindo Persada.

[8] Dr. Usman. 2010. Model-model pembelajaran mengembangkan profesionalisme guru. Jakarta: PT Raja Grafindo Pesrsada.

[9] Drs. Moh Uzer Usman. 2000. Menjadi Guru profesional. Bandung: PT Remaja Rosda karya. 
[10] Dr. E. Mulyasa. 2005. Menjadi guru profesional menciptakan pembelajaran kreatif dan menyenangkan. Bandung: PT Remaja Rosda karya.

[11] Prof. Dr. H. Buchari Alma. 2009. Guru Profesional menguasai metode dan keterampilan mengajar. Bandung: Alfabeta.

[12] Drs. Ad Rooijakkers. 1991. Mengajar Dengan Sukses petunjuk untuk merencanakan dan menyampaikan pengajaran. Jakarta: PT Grasindo.

[13] Saud, U. S. 2012. Pengembangan Profesi Guru. Bandung: Alfabeta.

[14] Suyadi. 2013. Strategi Pembelajaran Pendidikan Karakter. Bandung; PT Remaja Rosdakarya.

[14] Drs. Didi Supriadie, Dr. Deni Darmawan. 2012. Komunikasi Pembelajaran. Bandung: PT Remaja Rosdakarya. 